\title{
A DIETÉTICA \\ COMO PRÁTICA \\ DO DISCURSO \\ SOBRE A \\ LONGEVIDADE
}

\section{LA DIETÉTICA COMO PRÁCTICA DE EXPRESIÓN EN LA LONGEVIDAD}

DIETETICS AS A PRACTICE ON THE LONGEVITY DISCOURSE

\author{
Adélli Bortolon Bazza* \\ Daniela Polla* \\ Universidade Estadual de Maringá
}

RESUMO: A partir de uma série enunciativa composta de textos veiculados na mídia, propõe-se, neste artigo, analisar algumas práticas que constituem o discurso da longevidade. Essa temática está relacionada aos saberes produzidos sobre/para/por idosos atualmente. Tal interesse se justifica pelo aumento da população idosa e de sua relevância social no país, consequentemente, pela intensificação dos discursos a seu respeito. Baseado nos pressupostos de Michel Foucault, foram mobilizados os conceitos de discurso, subjetivação, práticas discursivas, cuidado de si e dietética. A análise dos enunciados demonstrou que, paralelamente à prática médica clínica, a dietética funciona como uma estratégia do cuidado de si no discurso sobre a longevidade e, como parte de um processo de subjetivação, os indivíduos sofrem coerção a adotá-la.

PALAVRAS-CHAVE: Discurso. Longevidade. Cuidado de si. Dietética.

RESUMEN: A partir de una serie expositiva compuesta de textos difundidos en los medios de comunicación, se propone en este artículo, analizar algunas prácticas que constituyen el discurso de la longevidad. Este tema está relacionado con el conocimiento producido sobre / para / por el ahora anciano. Tal interés se justifica por el aumento de la población anciana y su relevancia social en el país, por lo tanto, la intensificación de los discursos sobre ella. Con base en los supuestos de Michel Foucault, utilizamos los conceptos de discurso, la subjetificación, las prácticas discursivas, el autocuidado y la dietética. El análisis de los enunciados mostró que, además de la práctica médica clínica, la dieta funciona como una estrategia de auto-cuidado en el discurso sobre la longevidad y, como parte de un proceso subjetivo, las personas se ven obligadas a adoptarlas.

PALABRAS CLAVE: El discurso,. La longevidad. El cuidado de uno mismo. La dietética.

ABSTRACT: In this article we propose the analysis of some practices that constitute the discourse on life expectancy from an enunciative series composed of articles published in the media. This theme is related to the knowledge produced about/for/by the elderly nowadays. Such interest is justified by the increase in the elderly population, as well as their social relevance in the country,

\footnotetext{
*Doutoraem Letras pela UEM-PR. Professorado Departamentode Língua PortuguesadaUEM. E-mail:abbazza2@uem.br. 
which intensifies the production of discourses about them. Based on Michel Foucault's assumptions, we applied the concepts of discourse, subjectification, discursive practices, self-care and dietetics. The statements' analysis showed that, in addition to being a clinical medical practice, dieting also operates as a self-care strategy in discourses about life expectancy and, as it is a part of a subjectification process, all individuals are coerced to embrace it.

KEYWORDS: Discourse. Life expectancy. Self-care. Dietetics.

\section{INTRODUÇÃO}

A população idosa vem aumentando em diversas regiões do mundo. Fenômeno mais antigo na Europa, o chamado envelhecimento da população também foi constatado no Brasil por dados do Censo Demográfico (IBGE, 2010). De acordo com a pesquisa realizada pelo IBGE, houve um aumento da população com 65 anos ou mais, que era de 4,8\% em 1991, passou a 5,9\% em 2000, e chegou a $7,4 \%$ em 2010. Por estimativas, previu-se que o crescimento dessa faixa da população será gradual e atingirá 58,4 milhões (26,7\% do total) em 2060.

Esse aumento da quantidade de idosos torna-os objeto de interesse para diversos setores da sociedade. Devido a isso, desenvolvemse leis, produtos, serviços, um ramo da medicina, medicamentos voltados especificamente para esse público. E juntamente com a emergência desses bens, produtos e serviços, desenvolvem-se também saberes sobre o idoso.

Alguns fatores estão relacionados a essa mudança no perfil da população, entre eles a redução da taxa de natalidade, consequência da sociedade considerada moderna, na qual as pessoas trabalham muito e têm menos filhos. Além disso, têm grande destaque nesse processo os avanços da medicina e da farmacologia, que possibilitaram uma maior longevidade à população.

A temática da longevidade vem sendo recorrente em reportagens, notícias, programas de televisão, entre outros textos da mídia. A valorização da vida longeva e a recorrência desse discurso funcionam como uma forma de definir um tipo esperado de idoso e, para isso, são determinadas também práticas que levam o sujeito a essa condição. Tal reconfiguração de subjetividades tem sido objeto de discussões acadêmicas, como em Polla (2013) e Bazza (2016). Dentro desse processo mais amplo de subjetivação e a partir de uma perspectiva discursiva, baseada nos pressupostos de Michel Foucault, propõe-se, neste artigo, analisar algumas práticas que constituem o discurso da longevidade. Supõe-se que, paralelamente à medicação, a dietética funcione como estratégia de manutenção do discurso, da subjetivação e do cuidado do sujeito consigo mesmo.

No esteio da proposta foucaultiana, procurou-se, em meio à dispersão de acontecimentos, compor séries de enunciados e buscar neles as regularidades. A série a ser analisada é composta de enunciados da mídia que tenham a longevidade como temática principal.Para tanto, serão abordados os pressupostos teórico-metodológicos da proposta foucaultiana, tais como discurso, enunciado, subjetivação, cuidado de si, dietética. Por fim, procede-se o movimento descritivo-interpretativo de textos da mídia, a saber: uma reportagem publicada no siteda revista Alfa e uma capa da revista Época, ambas as materialidades abordando a regularidade do funcionamento da dietética e dos cuidados de si quando se trata do tema da longevidade.

\section{A DIETÉTICA COMO PRÁTICA DISCURSIVA}

Este trabalho tem como base teórico-metodológica a Análise do Discurso de linha francesa, particularmente aquela preconizada por Michel Foucault. Tido como historiador por uns, filósofo por outros, o arcabouço teórico-metodológico cunhado a partir da obra desse autor tem sido cada vez mais mobilizado para trabalhos com viés discursivo. Assim, apesar dele nunca ter aceitado que o enquadrassem, e nem ter deixado um método específico, sua obra é utilizada por estudantese pesquisadores em Análise do Discurso como "[...] uma espécie de 'caixa de ferramentas' usadas para quebrar as palavras, extraindo delas o que elas dizem, e quebrar as coisas, pondo à mostra suas visibilidades." (PEY; BACCA; SÁ, 2004, p. 20). 
Importa destacar que, nesta linha de pesquisa, não há descrição de vocabulário, nem a descrição de experiências, não se vai aquém nem além. Fica-se no nível do discurso. Foucault(2009a, p. 55) afirma que

[...] gostaria de mostrar que os "discursos", tais como podemos ouvi-los, tais como podemos lê-los sob a forma de texto, não são, como se poderia esperar, um puro e simples entrecruzamento de coisas e de palavras [...]; gostaria de mostrar que o discurso não é uma estreita superfície de contato, ou de confronto, entre uma realidade e uma língua, o intrincamento entre um léxico e uma experiência; gostaria de mostrar [...] que, analisando os próprios discursos, vemos se desfazerem os laços aparentemente tão fortes entre as palavras e as coisas, e destacar-se um conjunto de regras, próprias da prática discursiva.

As regras a que o autor se refere são as práticas discursivas, responsáveis por definir o regime dos objetos eformar os objetos de que falam. Dessa forma, considera-se que a emergência de um idoso que viva bastante está calcada em práticas que definem como se chegar à longevidade. Veyne (1998, p. 248) explica a noção: "prática não é uma instância misteriosa, um subsolo da história, um motor oculto: é o que fazem as pessoas". Essas práticas inscrevem-se na língua, na medida em que podem ser analisadas a partir de uma materialidade linguística, mas podem se constituir em outras materialidades, como os gestos, as cores, o som etc.

Há um conceito-chave para as análises que se baseiam em Michel Foucault: enunciado. Para esse autor, enunciado é muito mais do que a coisa dita, uma formulação, uma sequência linguística, enunciado é uma função de existência. Assim,

O enunciado não é, pois, uma estrutura (isto é, um conjunto de relações entre elementos variáveis, autorizando assim, um número talvez infinito de modelos concretos); é uma função de existência que pertence, exclusivamente, aos signos, e a partir da qual se pode decidir, em seguida, pela análise ou pela intuição, se eles "fazem sentido" ou não, segundo que regra se sucedem ou se justapõem, de que são signos, e que espécie de ato se encontra realizado por sua formulação. (FOUCAULT, 2009a, p. 98)

Nessa medida, tem-se um enunciado quando se puder descrever a função enunciativa, que compreende as características: referencial, posição-sujeito, campo associado e existência material. Cabe, portanto, descrever brevemente os quatro princípios da função enunciativa. Inicialmente, para Foucault (2009a, p. 103), o enunciado está ligado a um referencial, que

[...] forma o lugar, a condição, o campo de emergência, a instância de diferenciação dos indivíduos ou dos objetos, dos estados de coisa e das relações que são postas em jogo pelo próprio enunciado; define as possibilidades de aparecimento e de delimitação do que dá à frase seu sentido, à proposição seu valor de verdade.

Como segundo elemento da função enunciativa, o autor não fala em sujeito, mas em uma posição-sujeito. Não há um sujeito específico, mas uma posição vazia, que pode ser ocupada por vários enunciadores. Dessa forma, procura-se"[...] determinar qual é a posição que pode e deve ocupar todo indivíduo" para ser sujeito de determinado enunciado. (FOUCAULT, 2009a, p. 108). O terceiro elemento da função enunciativa é o campo associado. A compreensão discursiva é de que “[...] não há enunciado que não suponha outros: não há nenhum que não tenha, em torno de si, um campo de coexistências, efeitos de série e de sucessão, uma distribuição de funções e de papéis."(FOUCAULT, 2009a, p. 112). O campo associado compreende, portanto, a teia de relações discursivas em que um enunciado se inscreve. Como último elemento da função enunciativa, o enunciado precisa ter uma existência material. Ele precisa de uma superfície, um suporte, um lugar e uma data. Quando essa materialidade se altera, o próprio enunciado também se modifica (FOUCAULT, 2009a).

Ao ser tomado como objeto de análise, o discurso da longevidade se organiza a partir de uma função enunciativa, que propõe um referencial: o alongamento da vida; uma posição-sujeito a ser ocupada por pessoas que possam adotar as práticas necessárias para que a vida realmente seja estendida; um campo associado em que se constrói a relação com outros enunciados que tratam do idoso, da expectativa de vida em diversos lugares e em diversos momentos históricos; e também articula uma superfície em que isso se materializa: nesse caso, reportagens de revistas contemporâneas. 
Nos enunciados manifestam-se as práticas discursivas. Dessa forma, as coisas passam a ter existência apenas a partir do momento em que se tornam objeto de um discurso. Descrever um enunciado implica, então,

[...] determinar em que condições alguma coisa pôde se tornar objeto para um conhecimento possível, como ela pôde ser problematizada como objeto a ser conhecido, a que procedimento de recorte ela pôde ser submetida, que parte dela própria foi considerada pertinente. Trata-se, portanto, de determinar seu modo de objetivação, que tampouco é o mesmo de acordo com o tipo de saber em pauta. (FOUCAULT, 2006, p. 235)

Nesse sentido, quando se fala de algo, é porque as práticas e as regras a que ele obedece já tornaram-no objeto do discurso, em um momento histórico específico e perante condições restritas. "As práticas constituem [...] a realidade social de maneiras complexas e emaranhadas: elas são tanto os objetos de conhecimento [...] quanto os sujeitos conhecidos.” (OKSALA, 2011, p. 21). Assim, um "objeto natural" só se torna objeto para uma dada prática que o objetiva, por isso a prática vem em primeiro lugar. "Cada prática, tal como o conjunto da história a faz ser, engendra o objeto que lhe corresponde [...]. As coisas, os objetos não são senão correlatos das práticas." (VEYNE, 1998, p. 256).Em relação à velhice, as práticas de conservação da vida culminaram por criar não só o discurso da longevidade, mas instituíram a posição-sujeito longeva, especialmente para os idosos.

Em uma análise discursiva, depois de considerada a prática discursiva e verificados os enunciados, realiza-se a análise enunciativa, a qualdeve livrar-se da imagem do retorno, para descrever os enunciados não como a totalidade das significações ou em relação à interioridade de uma intenção, mas como

[...] um conjunto de enunciados para aí reencontrar não o momento ou a marca de origem, mas sim as formas específicas de um acúmulo, não é certamente revelar uma interpretação, descobrir um fundamento, liberar atos constituintes; não é, tampouco, decidir sobre uma racionalidade ou percorrer uma teleologia. É estabelecer o que eu chamaria, de bom grado, uma positividade. Analisar uma formação discursiva é, pois, tratar um conjunto de performances verbais, no nível dos enunciados e da forma de positividades que as caracteriza; ou, mais sucintamente, é definir o tipo de positividade de um discurso. (FOUCAULT, 2009a, p. 141-142)

Descrever a positividade de um discurso diz respeito não a analisar a formação discursiva em si, mas sim adar conta de seus quatro domínios, de seus elementos comuns. Nas palavras de Michel Foucault (2008, p. 107), a descrição da formação discursiva deve se preocupar com o "[...] jogo de suas defasagens, seus interstícios, suas distâncias - de qualquer forma, de suas lacunas, mais do que de suas superfícies plenas -, é isso que proporei chamar de sua positividade." A positividade de um discurso lhe caracteriza a unidade através dos tempos e extrapola os limites de obras, textos ou livros. Mais particularmente, "[...] essa forma de positividade (e as condições de exercício da função enunciativa) define um campo em que, eventualmente, podem ser desenvolvidos identidades formais, continuidades temáticas, translações de conceitos, jogos polêmicos.” (FOUCAULT, 2009a, p. 144).

Cumpre destacar que Foucault, com sua análise enunciativa, não tratou de descrever disciplinas ou ciências. Esse autor debruçouse sobre algo mais amplo: a constituição de saberes. Por saber compreende o

[...] conjunto de elementos, formados de maneira regular por uma prática discursiva e que são indispensáveis à constituição de uma ciência, apesar de não se destinarem necessariamente a lhe dar lugar [...]. Um saber é aquilo de que podemos falar em uma prática discursiva que se encontra assim especificada:o domínio constituído pelos diferentes objetos que irão adquirir ou não um status científico [...]; um saber é, também, o espaço em que o sujeito pode tomar posição para falar dos objetos de que se ocupa em seu discurso [...]; um saber é também o campo de coordenação e de subordinação dos enunciados em que os conceitos aparecem, se definem, se aplicam e se transformam [...]; finalmente, um saber se define por possibilidades de utilização e de apropriação oferecidas pelo discurso. (FOUCAULT, 2009a, p. 204)

$\mathrm{Na}$ constituição do discurso sobre a longevidade, estão entrelaçados diversos campos de conhecimento, como a medicina, a nutrição, a fisioterapia, a sociologia, a história. Nesse entrelaçamento, vai se delineando um saber mais específico, que determina o que é longevidade e quais práticas podem/devem ser seguidas para se alcançar a vida longeva. 
Baseando-se na obra foucaultiana, não há como dissociar a constituição de saberes das relações de poder que os perpassam, ao mesmo tempo em que os constituem. Sendo assim, saber e poder se completam. De acordo com Foucault (2007, p. 27), é preciso

[...] admitir que o poder produz saber (e não simplesmente favorecendo-o porque o serve ou aplicando-o porque é útil); que não há relação de poder sem constituição correlata de um campo de saber, nem saber que não suponha e não constitua ao mesmo tempo relações de poder. Essas relações de "poder-saber" não devem então ser analisadas a partir de um sujeito do conhecimento que seria livre ou não em relação ao sistema do poder; mas é preciso considerar ao contrário que o sujeito que conhece, os objetos a conhecer e as modalidades de conhecimentos são outros tantos efeitos dessas implicações fundamentais do poder-saber e de suas transformações históricas.

Nessa perspectiva, não se considera que a atividade do sujeito produziria um saber desligado do poder. Ao contrário: o poder-saber, os processos discursivos e as lutas pelo poder é que determinam os campos do conhecimento e, em última instância, possibilitam a constituição do sujeito tal qual se apresenta.

As relações de poder, em se tratando dos sujeitos idosos, foco deste trabalho, constituem-se como um biopoder. Poder que se volta para a vida, para o governo das populações. Um governo que não atua somente para

[...] formar e transformar o indivíduo pelo controle do tempo, do espaço, da atividade e pela utilização de instrumentos como a vigilância e o exame. Eles também se realizam pela regulação das populações, por um biopoder que age sobre a espécie humana, que considera o conjunto. (MACHADO, 1998, p. XXII)

De acordo com Foucault (2009b, p. 151), na biopolítica, "[...] é sobre a vida e ao longo de todo o seu desenrolar que o poder estabelece seus pontos de fixação; a morte é o limite, o momento que lhe escapa." Essa forma de governo centra-se em mecanismos, táticas e técnicas de controle do corpo geral da população. O regime das relações de poder "[...] volta-se para a população através de mecanismos reguladores que visam a estabelecer e manter o equilíbrio dessa população, de forma que a vida seja otimizada. Enquanto a disciplina é centrada no corpo [...] o biopoder foca a vida." (LACHI; NAVARRO, 2012, p. 33). No caso dos idosos, isso se torna mais visível pelo fato de, em tese, a velhice ser a fase do declínio da saúde e da preparação para a morte. Sendo assim, tornase importante gerir o corpo idoso de modo a retardar, senão a morte, ao menos o declínio físico.

A partir da descrição da biopolítica, com a publicação do segundo e terceiro volumes da História da Sexualidade(1998, 2005),Foucault volta-se ao exame das tecnologias do eu, das relações consigo mesmo, da subjetivação, concebida como "[...] todos aqueles procedimentos destinados a constituir subjetividades, verdades do e sobre o sujeito, nos mais diferentes espaços, práticas e discursos, e sempre articulados a relações de poder" (FISCHER, 2012, p. 46). Essas técnicas de si são procedimentos, formas de governo de si e dos outros. O conjunto delas"[...] propõe não só o 'conhecer-se', mas também o governar-se: autodecifrar-se, confessar-se ao outro, examinar-se, sacrificar-se." (GREGOLIN, 2007, p. 48-49). Tais práticas tornam-se instrumentos de uma arte de existência, com vistas a um determinado fim, que pode, entre outros, ser o de otimizar a vida e adiar seu declínio. Nesse caso, podem se constituir como elementos possibilitadores da longevidade.

Em seu livro História da Sexualidade III(2005), Foucault volta-se a textos do período clássico grego, com o objetivo de descrever práticas que orientavam a vida dos indivíduos naquela sociedade. $\mathrm{O}$ autor vai aos gregos como uma forma de entender a atualidade,guiado pela hipótese de que tais práticas possam guardar uma permanência e orientar também a constituição dos sujeitos modernos.

Foucault (2005, p. 46) faz uma problematização social e moral das práticas do cuidado de si e constata, nos textos dos primeiros séculos, que

[...] a insistência sobre a atenção que convém ter para consigo mesmo; é a modalidade, a amplitude, a permanência, a exatidão da vigilância que é solicitada; é a inquietação com todos os distúrbios do corpo e da alma que é preciso evitar por meio de um regime austero; é a importância de se respeitar a si mesmo. 
Tais ações ultrapassam o simples objetivo de determinar o proibido ou o permitido, mas ocasionam uma intensificação da relação consigo, por meio da qual o indivíduose constitui enquanto sujeito de seus atos.

A cultura de si é um tema que abarca a todos e deve ser seguido por toda a vida. Além disso, essa atenção não pode ser difusa, pois implica um trabalho constante do sujeito. Foucault (2005, p. 50) afirma que

[...] ocupar-se consigo mesmo é em todo caso um imperativo que circula entre numerosas doutrinas diferentes; ele também tomou a forma de uma atitude, de uma maneira de se comportar, impregnou formas de viver; desenvolveu-se em procedimentos, em práticas e em receitas que eram refletidas, desenvolvidas, aperfeiçoadas e ensinadas; ele constituiu assim uma prática social, dando lugar a relações interindividuais, a trocas e comunicações e até mesmo a instituições; ele proporcionou, enfim, um certo modo de conhecimento e a elaboração de um saber.

Por ser desenvolvido na vida privada e não ser visível, o trabalho sobre si poderia gerar a impressão de que se tratava de um tempo vazio. Foucault, porém, descreve inúmeras práticas desse cuidado consigo, e entre elas estão: o cuidado com o corpo, os regimes de saúde, os exercícios físicos sem excesso, a satisfação ponderada das necessidades. O autor constatou que o cuidado de si se desenvolve em uma correlação estreita com o pensamento e a prática médica. No caso dos gregos, isso implicou no aumento do cuidado médico e da atenção dada ao corpo. A medicina produziu saberes sobre o corpo a partir de uma dietéticaque definia "[...] uma maneira de viver, um modo de relação refletida consigo, com o próprio corpo, com o alimento, com o sono, com as diferentes atividades e com o meio." (FOUCAULT, 2005, p. 106). A dietética funcionou, portanto, como uma prática social e discursiva que constituía o sujeito moral da cultura clássica. Além disso, guarda um efeito de atualidade, pois atua na constituição do sujeito contemporâneo.

Em relação à sua observação de textos gregos e romanos, Foucault constata uma intensa discussão sobre o que se devia comer ou não em cada época ou situação. O autor afirma que "[...] o cuidado principal dessa reflexão era definir o uso dos prazeres - suas condições favoráveis, sua prática útil e sua refração necessária - em função de uma certa maneira de ocupar-se do próprio corpo." (FOUCAULT, 1998, p. 89). Existia uma dieta própria aos doentes, a qual não era indicada para as pessoas que estavam bem de saúde. O autor relaciona a gênese da dietética ao momento em que os homens abandonam a vida rude e começam a cuidar das doenças. Dessa forma, ela se configura "[...] como uma espécie de medicina para os tempos de lassidão; ela era destinada às existências mal conduzidas e que buscam prolongar-se." (FOUCAULT, 1998, p. 92).

Mas o significado da dietética ampliou-se e passou a se projetar nas vidas daqueles que, estando sadios, organizavam suas ações de modo a adaptar seu organismo às condições e, dessa forma, poupá-lo. Dessa perspectiva, Foucault (1998, p. 93) afirma que

[...] a própria 'dieta', o regime, é uma categoria fundamental através da qual pode-se pensar a conduta humana; ela caracteriza a maneira pela qual se conduz a própria existência, e permite fixar um conjunto de regras para a conduta: um modo de problematização do comportamento que se faz em função de uma natureza que é preciso preservar e à qual convém conformar-se. O regime é toda uma arte de viver.

Como parte dessa arte de viver, o regime problematiza uma relação do sujeito com seu corpo e desenvolve um modo de vida em função do cuidado com o corpo. Contudo, a função da dietética na constituição dos sujeitos excede o limite do corpo e desvela uma ética para a existência, entre outras coisas porque “[... o regime tem que estabelecer uma medida [...] é útil 'o que está na justa medida." (FOUCAULT, 1998, p. 94). Desse modo, seguir um regime impinge ao sujeito uma ponderação acerca de medidas e pontos de equilíbrio que, como prática,podem extrapolar essa situação imediata e ser aplicada a outras situações do cotidiano. Segundo Foucault (1998, p.98), "[...] a prática do regime enquanto arte de viver é bem outra coisa do que um conjunto de precauções destinadas a evitar as doenças ou terminar de curá-las. É toda uma maneira de se constituir como um sujeito que tem por seu corpo o cuidado justo, necessário e suficiente." Esse ponto de equilíbrio muitas vezes é associado à longevidade. Por isso, a busca por uma dietética e por práticas de cuidado de si que visem a uma justa medida é recorrente na formação do discurso sobre a velhice e a longevidade. 
Dessa forma, a dietética se constitui como uma arte estratégica, uma técnica do sujeito sobre si, porque lhe permite conduzir seu corpo de forma refletida, de acordo com as circunstâncias. Assim, a patologia pode ser associada à falta de economia, na medida em que ocorreria em sujeitos que não fizeram certa "economia" do uso dos prazeres para evitar "consequências danosas" ao próprio organismo. Nesse sentido, o exagero prejudica, ao passo que certo equilíbrio beneficia, sobretudo o equilíbrio por meio da técnica da "temperança" (FOUCAULT, 2005).

Em termos foucaultianos, o discurso sobre a longevidade funciona como um elemento que define uma ordem do discurso, posto que inclui uns enquanto exclui outros e, portanto, leva-os a buscarem uma adequação. Essa inclusão pode acontecer se o sujeito, nesse caso o idoso, adotar práticas de cuidado de si que sejam constituintes do discurso da longevidade. Na sequência será analisada uma série enunciativa composta de textos que circularam na mídia, com o intuito de descrever as práticas que compõem esse discurso.

\section{DIETÉTICA E LONGEVIDADE EM TEXTOS MIDIÁTICOS}

Apesar de Foucault analisar,na História da Sexualidade II(1998), textos gregos e romanos da época clássica, conceitos como a dietética podem perfeitamente ser percebidos nos discursos atuais. Especialmente em preocupações contemporâneas objetivadas nos discursos. Um exemplo disso é o caso das sequências enunciativas acerca da longevidade que constituem a série enunciativa a ser analisada. Tendo em vista que a mídia é um dos principais dispositivos que fala e faz falar sobre idosos, optou-se por recortar textos de revistas com ampla circulação nacional, abordando o suporte impresso e o digital para abarcar mais amplamente a temática da longevidade.

No site da Revista $A l f a^{l}$, mantido pela editora Abril, foi publicada, em vinte e cinco de abril de dois mil e treze, uma matéria intitulada 15 coisas que seu médico não vai te contar sobre longevidade, a qual se mostra particularmente frutífera para a análise dos temas elencados por Michel Foucault ao apresentar a dietética. O jornalista que assina a matéria é Emiliano Urbim. Seu texto cita uma pesquisa iniciada em 1921 pelo médico Lewis Terman, na Universidade Stanford-Califórnia, que tinha como objetivo analisar um grupo de 1.500 crianças para acompanhar a evolução de sua qualidade de vida. Os resultados da pesquisa foram divulgados em 2012. Como já mencionado, muito mais do que uma dieta ou um regime, a dietética é uma arte de existência, uma forma de governar o próprio corpo. Essa afirmação está presente na matéria do site daAlfa, em sequências enunciativas tais como: "bons hábitos e fatores externos que são fundamentais para se chegar a uma 'melhor idade' digna do nome”. Essa afirmação pode ser aproximada à noção dietética de que importa ter uma vida útil e feliz no tempo que for permitido.

Além disso, o tratamento da longevidade está relacionado à "melhor idade”. A opção por essa nominação divide espaço no campo associado com outras formas de nomear a fase que se vive depois dos sessenta anos: terceira idade e velhice. Principalmente a velhice está associada a memórias negativas das perdas e do declínio físico que a idade traz. A noção de terceira idade costuma ser relacionada a uma nova maneira de viver a velhice, com ênfase na atividade, nas relações sociais; mas ainda considera os aspectos negativos do envelhecimento. Já a expressão 'melhor idade' opera retomando apenas os aspectos positivos dessa fase, enquanto produz um apagamento das perdas que se sofre. Dessa forma, cria-se o efeito de que o exercício de uma dietética garantirá não só a longevidade, mas a velhice feliz.

Outra sequência enunciativa em que essa prática se manifesta é: "Boa parte dessas novas regras são desdobramentos de estudos que levam em conta a influência que a sua personalidade e o seu entorno podem ter na sua longevidade”. Por um lado, apresentam-se aspectos externos ao sujeito como responsáveis por garantir a vida longa; por outro, a afirmação de que a personalidade pode contribuir traz para o sujeito questões sobre as quais se acredita poder trabalhar. Ao determinar uma personalidade desejável para viver mais, estão incluídos na longevidade aqueles que têm esse comportamento, e excluídos aqueles que agem de outra forma. Passa a operar, dessa forma, a injunção sobre os indivíduos para que desenvolvam outra prática em relação a sua personalidade e possam,

\footnotetext{
${ }^{1}$ Para a matéria completa, vide Anexo I.
} 
assim, assumir a posição-sujeito oferecida pelo discurso da longevidade. Essa visão retoma a ideia de que a dietética faz parte de uma arte de existência que é física e moral. Dito de outro modo, há no texto uma prescrição da arte de existência que precisaser mantida para se ter longevidade e chegar à "melhor idade".

Nos discursos da atualidade, figura um conjunto de regras em certa medida já internalizadas pelos indivíduos como artes de "bem viver", para ser saudável e conseguir longevidade.Isso pode ser percebido quando o texto da matéria coloca que "Os conselhos clássicos de se manter ativo, bem alimentado e tranquilo continuam valendo, claro". Opera-se uma retomada de memória marcada pela expressão "continuam valendo", o que indica que há um saber partilhado e já tomado como verdadeiro a respeito de práticas de longevidade. Esse saber está assentado na prática de uma alimentação saudável, de uma vida ativa e de uma tranquilidade psicológica do sujeito. Essas práticas indiciam a amplitude da dietética da qual o sujeito deve se valer para alcançar a longevidade: opera-se no campo da nutrição, do cuidado com o corpo e do cuidado com a alma.

A partir do excerto anterior, pode-seretomar a afirmação de Foucault de que a dietética envolve também questões morais, tais como a firmeza para seguir essas prescrições ou o conselho de 'manter-se tranquilo'. Além disso, quando prescreve a manutenção da atividade, essa sequência retoma o que a dietética aborda a respeito dos exercícios e cuidados com ocorpo como prática do cuidado de si. Nesse caso, a noção da busca da longevidade se constitui como regularidade no discurso acerca dos idosos. Mas também atinge outras faixas etárias, pois a prática de exercícios físicos, assim como a dietética, tem sido difundida na atualidade como algo a se seguir por toda a vida. Trata-se de uma busca pela longevidade que se inicia ainda na infância.

O texto de Emiliano Urbim apresenta outras quinze lições e dicas prescritas pelos resultados da pesquisa do grupo da Universidade Stanford. Conselhos esses que são introduzidos da seguinte maneira: "Conheça essas e outras lições nas próximas páginas. Afinal, o negócio não é só chegar a 100: é chegar bem”. Esse último período, ao afirmar que, mais do que uma vida longeva, importa uma existência boa, relaciona-se ao que Foucault (1998, p. 96)defende na dietética a respeito de que não importa levar a vida o mais longe possível no tempo, "[...] mas torná-la útil e feliz nos limites que lhe foram fixados." Há, na sequência enunciativa mobilizada, o caráter prescritivo materializado pelo verbo no imperativo mais a palavra lição. Essa construção confere efeito de verdade, bem como exerce a função de incluir/excluir típica da ordem dos discursos e, por meio disso, estabelece a coerção ao sujeito para a adoção de tal modelo de cuidado de si.

Na sequência da matéria, o autor apresenta as “15 coisas que seu médico não vai te contar sobre longevidade”. Quais sejam:

1 - Nunca, nunca se aposente; 2 - Passar fio dental faz bem para o coração; 3 - Otimismo faz mal para a saúde; 4 - Socializar é a fonte da juventude; 5 - Deus ajuda quem vai à igreja; 6 - Beba. E não precisa ser tacinha de vinho; 7 - Palavras cruzadas salvam vidas; 8 - Mulher: o negócio é imitar; 9 - Não fique viúvo. Você não sabe se cuidar sozinho; 10 - Pare de se incomodar com bobagem; 11 - Não confie nos seus genes; 12 - Não tenha amigos legais. Tenha amigos saudáveis; 13 - Tenha filhos - ou algo parecido, como cachorros; 14 - Seja bom no que você faz. Ao menos tente; 15 - Ser um pouco hipocondríaco vale a pena.

Assim, por meio do título da matéria e das “15 coisas”, verifica-se a separação entre o saber médico e a dietética. Isso porque a matéria aborda tópicos de que a medicina não trata, bem como permite observar que a prática médica é o cuidado do médico para com o sujeito, enquanto a dietética trata do cuidado do sujeito para com ele mesmo.

Esses conselhos permitem perceber o que Foucault (1998) afirma quando define a dietética como uma maneira de ocupar-se do próprio corpo, já que as 15 coisas, as quais - deacordo com a matéria - os médicos não contam a respeito da longevidade, prescrevem hábitoscomo usar fio dental, beber, ter amigos saudáveis, fazer palavras-cruzadas ou usar remédios. Ao mesmo tempo, essas orientações contemplam as questões morais também inclusas pelo autor francês na dietética: não se incomodar com bobagens, ter alguém pra cuidar, procurar ser bom no que se faz.

A dietética envolve, enfim, muitos e variados aspectos no que diz respeito aos cuidados consigo mesmo, as técnicas de si, a respeito de certa arte de existência. Isso pode ser percebido igualmente na capa da revista Época do dia três de julho de dois mil e dez, a qual

Bazza \& Pola | A dietética como prática do discurso sobre a longevidade 
tem como chamada principal "Os segredos da vida longa", sendo a linha de apoio: "Cientistas descobriram os genes da longevidade. Como isso pode nos ajudar a chegar aos 100 anos (até você, que não gosta muito de exercícios físicos e curte uma friturinha)”.

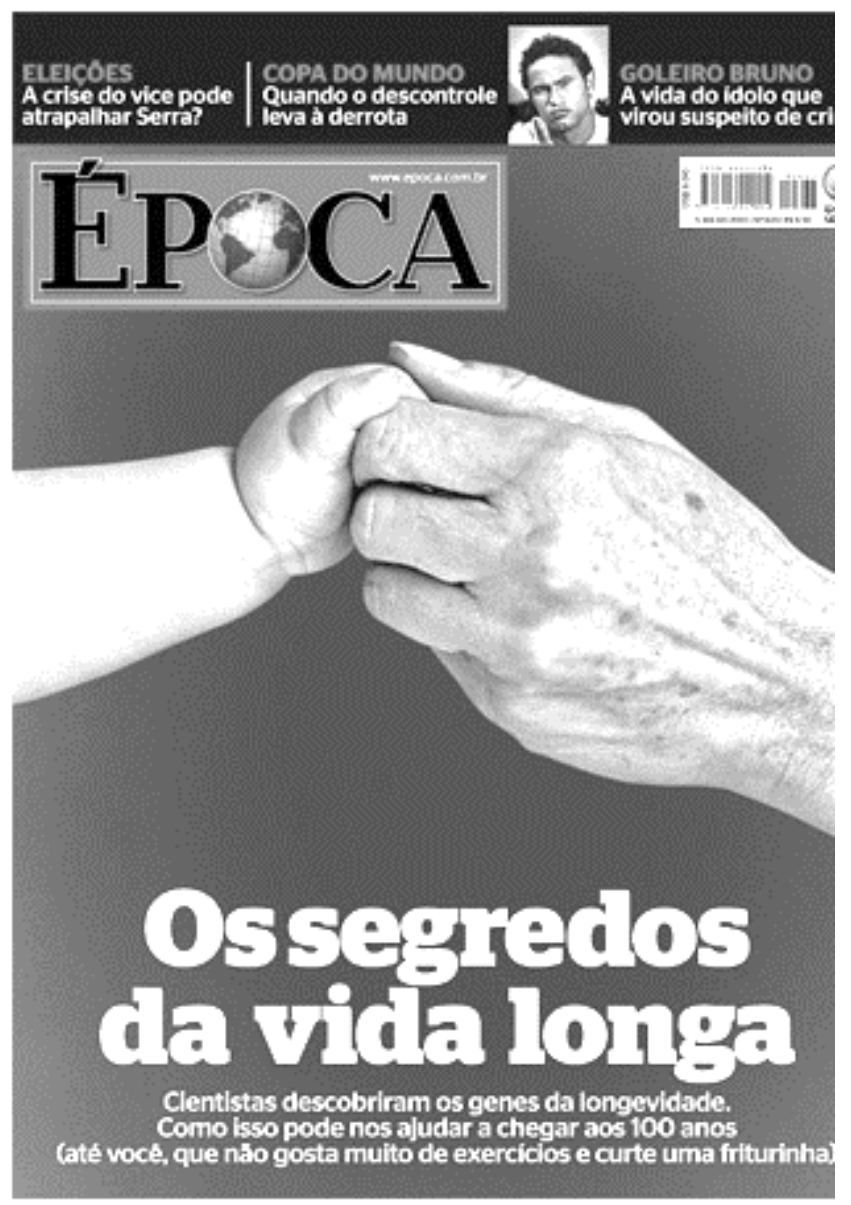

Figura 1: Capa revista Época

A parte imagética dessa capa apresenta a união de duas mãos: a de uma criança - suposta pelo tamanho - e a de um idoso - suposta pelas manchas que costumam aparecer com a idade. Considerada um enunciado, essa imagem é constitutiva da objetivação discursiva de idoso da contemporaneidade, pois metaforiza o ideal da dietética dos sujeitos idosos: envelhecer sem perder o vigor da juventude.Pode-seinterpretar a junção das duas pontas da linha da vida a partir da continuidade do vigor na velhice. Enquanto em alguns enunciados a longevidade é descrita como possível somente a partir das práticas dietéticas, nesse ocorre um atravessamento da questão biológica: haveria genes que favoreceriam viver mais e a descoberta desses genes é apresentada como um dos segredos da vida longa que serão revelados na revista.

Paralelamente à questão fisiológica, percebe-se a dietética funcionando nessa capa pela retomada da "justa medida" do que é útil ao corpo. Isto porque a sequência enunciativa "até você, que não gosta muito de exercícios físicos e curte uma friturinha" aciona um domínio associado do discurso acerca dos hábitos saudáveis, do qual não fazem parte o sedentarismo e o consumo de frituras, pois a vida saudável estaria relacionada a práticas dietéticas determinadas: exercícios físicos e alimentação livre de gorduras. Contudo, opera um deslocamento nele, ao propor uma flexibilização dessas práticas.A capa de Época mostra que se pode chegar aos cemanos mesmo não gostando muito de exercícios e consumindo fritura, desde que na justa medidaque não faça mal ao corpo. Dito de outro modo, trata-se da arte da temperança. A dietética continua manifestada, justamente porque passa de um regime radical para buscar uma justa medida que possa ser seguida a vida toda. 


\section{CONSIDERAÇÕES FINAIS}

Este artigo trouxe, de modo geral, a partir da perspectiva foucaultiana, e mobilizando as noções de discurso, enunciado, subjetivação, cuidado de si e dietética, uma discussão acerca dos discursos midiáticos que circulam na sociedade contemporânea a respeito da longevidade. Discursos esses que funcionam enquanto parte de um processo de subjetivação dos indivíduos como uma estratégia de cuidado de si, imposta ao sujeito que envelhece.

Como o texto mostrou, a temática da longevidade vem sendo recorrente em reportagens, notícias, programas de televisão, entre outros textos da mídia, nos quais a valorização da vida longeva e a recorrência desse discurso funcionam como uma forma de definir um tipo esperado de idoso. Isso determina também as práticas que levam o sujeito a essa condição.

Analisando duas reportagens - materialidades que abordam a regularidade do funcionamento da dietética e dos cuidados de si quando se trata do tema longevidade -, buscou-se uma discussão sobre a dietética como prática discursiva e uma estratégia do biopoder. Assim, constatou-se quea dieta observada por Foucault (1998) em discursos gregos e romanos do período clássico aparece também nas discursividades contemporâneas. Como demonstrado no esboço descritivo-analítico, essa dietética atual parece funcionar especialmente em discursos prescritivos a respeito da busca por viver mais, por manter o corpo jovem, ativo, saudável.

Dessa forma, percebe-se a dietética e a arte da temperança como regularidades quando se trata do tema de longevidade. Assim, a prática discursiva pode ser descrita como associando a longevidade a uma dietética, aquela dos exercícios físicos e de uma alimentação saudável, ao mesmo tempo em que é dissociada da prática médica, no sentido de que há técnicas de si não abordadas pelo saber médico que podem contribuir para a objetivação de uma longevidade.

Verifica-se, igualmente, que os cuidados de si para uma dietética da longevidade passam por cuidados físicos e também morais. Estas técnicas de si passam pela arte da temperança, no sentido de adotar técnicas na justa medida do que é útil ao corpo. Assim, atesta-se o funcionamento de uma dietética na objetivação contemporânea da longevidade.

\section{REFERÊNCIAS}

BAZZA, A. B.Subjetivação no discurso do idoso em contexto de estudos na UNATI-UEM. 2016. 132 f. Tese (Doutorado em Letras) Programa de Pós-Graduação em Letras, Universidade Estadual de Maringá, Maringá, 2016;

FISCHER, R. M. B. Trabalhar com Foucault:arqueologia de uma paixão. Belo Horizonte: Autêntica Editora, 2012.

FOUCAULT, M. Arqueologia do saber. 7. ed. Rio de Janeiro: Forense Universitária, 2009a.

. História da sexualidade I.A vontade de saber. 19. ed. Rio de Janeiro: Edições Graal, 2009b.

. História da sexualidade II. O uso dos prazeres. Rio de Janeiro: Graal, 1998.

. História da sexualidade III.O cuidado de si. Rio de Janeiro: Graal, 2005.

Vigiar e punir: nascimento da prisão. 34. ed. Petrópolis, RJ: Vozes, 2007.

1968 - Sobre a arqueologia das ciências. resposta ao círculo de epistemologia. In: FOUCAULT, M. Arqueologia das ciências e história dos sistemas de pensamento.2. ed. Rio de Janeiro: Forense Universitária, 2008. p. 82-118. (Coleção Ditos e escritos; II). 
IBGE Instituto Brasileiro de Geografia e Estatística.Notícias. Primeiros Resultados definitivos do Censo de 2010. Disponível em:<http://censo2010.ibge.gov.br/noticias-censo?view=noticia\&id=1\&idnoticia=1866\&t=primeiros-resultados-definitivoscenso-2010-populacao-brasil-190-755-799-pessoas>. Acesso em: 20 jul. 2016.

LACHI, P.; NAVARRO, P. O corpo moldado: corporeidade mediada e subjetivação. In: TASSO, I.; NAVARRO, P. (Org.) Produção de identidades e processos de subjetivação em práticas discursivas. Maringá: Eduem, 2012.

MACHADO, R. Introdução: Por uma genealogia do poder. In: FOUCAULT, M. Microfísica do Poder. 13. ed. Rio de Janeiro: Edições Graal, 1998. p. VII-XXIII.

MORAES, A. O corpo no tempo: velhos envelhecimentos. In:DEL PRIORI, M.; AMANTINO. M.(Org.).História do corpo no Brasil. São Paulo: Unesp, 2011.

OKSALA, J. Como ler Foucault. Tradução de Maria Luiza X. de A. Borges. Rio de Janeiro: Zahar, 2011.

PEY, M. O.; BACCA, A. M.; SÁ, R. S. Nas pegadas de Michel Foucault:apontamentos para a pesquisa de instituições. Rio de Janeiro: Achiamé, 2004.

REVISTA ÉPOCA. São Paulo, n. 633, 5jul. 2010.

POLLA, D. Objetivação e subjetivação do sujeito idoso pelas lentes da mídia contemporânea. 2013. 112 f. Dissertação (Mestrado em Letras) - Centro de Ciências Humanas, Letras e Artes, Universidade Estadual de Maringá, Maringá, 2013. Disponível em: $<$ http://www.ple.uem.br/defesas/def_daniela_polla.htm>. Acesso em: 20 set. 2016.

URBIN, E. 15 coisas que seu médico não vai te contar sobre longevidade. Revista Alfa. Disponível em: $<$ http://politicaspublicaseeducacao.blogspot.com.br/2014/01/saude-15-coisas-que-seu-medico-nao-vai.html>. Acesso em: 15 ago. 2016.

VEYNE, P. Como se escreve a história: Foucault revoluciona a história. Tradução de Alda Baltar e Maria A. Kneipp. 4. ed. Brasília: Editora Universidade de Brasília, 1998. 


\section{ANEXO A - 15 COISAS QUE SEU MÉDICO NÃO VAI TE CONTAR SOBRE LONGEVIDADE}

Fazer exercícios, controlar o estresse, maneirar no sal - estas regras você já sabe ou deveria saber, de tanto que os médicos repetem. Conheça agora ensinamentos para viver mais que não passam pelos consultórios

Por Emiliano Urbim Ilustrações Sattu19h43 25/04/2013

Alimentação balanceada, exercícios regulares, álcool sob controle, cigarro à distância, muitas horas de sono. Se tudo isso já faz parte da sua rotina, parabéns: você cumpre alguns dos pré-requisitos para viver mais. Acontece que há muitos outros: bons hábitos e fatores externos que são fundamentais para se chegar a uma "melhor idade" digna do nome.

Boa parte dessas novas regras são desdobramentos de estudos que levam em conta a influência que a sua personalidade e o seu entorno podem ter na sua longevidade. O principal deles é um estudo da Universidade Stanford, na Califórnia, iniciado pelo médico Lewis Terman em 1921. Naquele ano, ele selecionou um grupo de 1500 crianças para acompanhá-las durante os anos seguintes. Terman faleceu em 1958, mas seus assistentes (e os assistentes deles) seguiram acompanhando todo o grupo durante décadas, na alegria e na tristeza, na riqueza e na pobreza, até que suas mortes os separassem.

Em 2012, as conclusões foram apresentadas. Os conselhos clássicos de se manter ativo, bem alimentado e tranquilo continuam valendo, claro. Mas os pesquisadores chegaram a algumas informações surpreendentes: trabalhar muito é um caminho para viver muito, otimismo de mais pode ser prejudicial e a genética não é assim tão determinante para prever seu futuro. Conheça essas e outras lições nas próximas páginas. Afinal, o negócio não é só chegar a 100: é chegar bem.

\section{1- Nunca, nunca se aposente}

Pesquisas que comparam trabalhadores e aposentados da mesma idade mostram: quem parou está pior. Claro, vai depender da sua rotina. Mas como sabemos que a poltrona é tentadora, fique esperto. Não precisa trabalhar muito, nem todo dia - ache um hobby, um curso, um compromisso regular. E, não, assistir TV não conta como hobby.

\section{Passar fio dental faz bem para o coração}

O que uma coisa tem a ver com a outra? Acompanhe o raciocínio: se você não passar fio dental, vai acumular placa bacteriana, que vai causar gengivite, que vai provocar a liberação de substâncias conhecidas como químicos da inflamação, que são os vilões por trás de várias doenças cardíacas. Mas se isso não for argumento suficiente pra você... poxa, gengiva inflamada, dentes em falta e mau hálito não ajudam ninguém na terceira idade.

\section{Otimismo faz mal à saúde}

Enxergar apenas o lado bom das coisas tem seu lado ruim. Pois é: pessoas otimistas tendem a subestimar riscos - um traço de personalidade que pode levar de ultrapassagens ousadas a longas ausências no médico. Além disso, otimismo além da conta deixa você frustrado demais com as dificuldades da vida. Ou seja: com um pé atrás, você vai mais longe.

\section{Socializar é a fonte da juventude}

Quanto mais velhos, menos saímos de casa. Lute contra isso: a ciência garante que conviver com outros é o gatilho de benefícios físicos e mentais que prolongam a vida.

\section{Deus ajuda quem vai à igreja}

Fato: quem comparece à missa, culto, centro espírita, sinagoga, terreiro etc. em geral vive mais. Dilema: religiosos vivem mais porque rezam ou rezam porque vivem mais? Os dados não permitem concluir se a saúde dos anciãos é beneficiada pela experiência ou se, na verdade, quem tem disposição para ritos religiosos são justamente os mais saudáveis. Moral da história: na dúvida, tenha fé em alguma coisa - nem que seja em Richard Dawkins.

\section{Beba. E não precisa ser tacinha de vinho}

Quando o assunto é álcool e longevidade, só se fala em vinho tinto. Preconceito: vinho branco, cerveja, uísque e outros fermentados e destilados também podem fazer bem. Há um índice menor de doenças cardiovasculares relacionado ao consumo diário de até duas doses - e de apenas uma para mulheres, ponto para os homens! Mas a ALFA e o Ministério da Saúde advertem: beba com moderação. Passou de duas doses, já vira problema. 


\section{Palavras cruzadas salvam vidas}

Atividades que exercitam seu cérebro mantêm sua inteligência e prolongam sua lucidez. Opções não faltam: palavras cruzadas, xadrez, videogame, sudoku, qual-é-a-música. Detalhe: assim que estiver craque, troque de treino - seus neurônios só mantêm o frescor enfrentando novos desafios.

\section{Mulher: o negócio é imitar}

Elas vão mais ao médico, comem melhor, fumam menos, envolvem-se em menos acidentes e, assim, vivem mais. Então, deixe de frescura: seja mais feminino.

\section{Não fique viúvo. Você não sabe se cuidar sozinho}

Não bastasse haver cinco viúvas para cada viúvo no Brasil, elas ainda vivem muito mais depois de perder seus maridos do que nós após perdermos a esposa. A verdade é que, sozinhos, tendemos ao caos - o que aos 30 anos tem seu charme, mas em uma idade avançada é fatal. Então, não fique solteiro: sua saúde agradece.

\section{Pare de se incomodar com bobagem}

Mágoa, rancor, ressentimento: se ao ler essa lista você já recorda de vários exemplos pessoais, calma. Não é por aí. Se cultivados, esses sentimentos descambam na produção de cortisol, um hormônio que ataca seu coração, metabolismo e sistema imunológico. Diversos estudos relacionam uma alta taxa de cortisol a uma morte precoce. Portanto, aprenda a perdoar, relevar, deixar pra lá. Como dizia o guru indiano Meher Baba: Don’tworry, behappy - pois é, também achava que vinha daquela música.

\section{Não confie nos seus genes}

"Meu avô viveu 90 anos, não preciso me preocupar." Precisa. Uma nova pesquisa concluiu que apenas 25\% da duração da nossa vida podem ser atribuídos à herança genética; os outros 75\% dependem de você. Se quiser chegar aos 90 como o seu avô, descubra como ele fez para chegar lá.

\section{Não tenha amigos legais. Tenha amigos saudáveis}

OK, eles não são excludentes. Mas o ponto é: da mesma maneira que, para ganhar dinheiro, é melhor se cercar de ricos, e para emagrecer convém conviver com magros, para se ter saúde a receita é arranjar uma turma saudável - você melhora sem querer querendo.

\section{Tenha filhos - ou algo parecido, como cachorros}

Caso tenha se ofendido, por favor, volte ao item 10. Pronto. É o seguinte: possuir uma conexão com alguém mais jovem que você (filho, enteado, sobrinho, neto) é algo que te mantém interessado pelo mundo à sua volta - e mais a fim de continuar vivendo nele. E, sim, cachorro e gato também contam: além de manter você conectado, curtir um animal de estimação libera ocitocina, o hormônio benéfico liberado na convivência pais e filhos.

\section{Seja bom no que você faz. Ao menos tente}

Quanto menos trabalho, melhor. Esse conselho, que parece vindo do personagem Macunaíma, de Mário de Andrade, foi durante muito tempo adotado pelos especialistas em longevidade. Acreditava-se que uma vida sem esforço seria uma vida longa. Mas os médicos observaram que parece haver uma relação entre longevidade e empenho profissional. Por incrível e justo que pareça, passar décadas se dedicando e evoluindo em algo que você valoriza, ou seja, ralando muito, pode lhe valer vários anos a mais. Ao menos, garantem os especialistas, em comparação com quem passar o mesmo bocado de tempo trabalhando no que não gosta - essa sim é uma receita garantida para viver menos e pior.

\section{Ser um pouco hipocondríaco vale a pena}

Você vai continuar sendo considerado chato pela maioria dos amigos, mas pesquisas apontam que quem desconfia mais da própria saúde vive mais. No caso, é melhor prevenir e se remediar. 